\title{
Sir P. I. and the Hard-Boiled Knight
}

\author{
Julia CONSTANTINO \\ Universidad Nacional Autónoma de México
}

Over the entrance doors, which would have let in a troop of Indian elephants, there was a broad stainedglass panel showing a knight in dark armor rescuing a lady who was tied to a tree and didn't have any clothes on but some very long and convenient hair. The knight had pushed the vizor of his helmet back to be sociable, and he was fiddling with the knots on the ropes that tied the lady to the tree and not getting anywhere. I stood there and thought that if I lived in the house, I would sooner or later have to climb up there and help him. He didn't seem to be really trying.

Raymond Chandler, The Big Sleep

Taking into account the role played by the reader in the experience of reading, it can be said that the horizon of expectations of a work includes, among other things, past and present readings of past and present texts. Each new reading takes part in the dialectics of retention and protension which, at the level of the process of reading itself, Iser regards as the essence of the reader's wandering viewpoint. ${ }^{1}$ Thus, the position of the reader in a specific historical moment cannot be overlooked if the act of reading is to be considered as a dialogue between reader and text(s), and between the different historical moments to which they belong. This is a dialogue where the work's historical context is surrounded by the context of the reader's present - which, as it has been said, includes his/her reading experience- in a way that produces the interaction of past and present. ${ }^{2}$

'Wolfgang ISER, The Act of Reading: A Theory of Aesthetic Response, pp.107-134.

2 Hans Robert JAUSs, "Literary History as a Challenge to Literary Theory", in New Literary History: A Journal of Theory and Interpretation, vol. II, núm. 1, p. 20. 
It has to be emphasized that when the reader approaches a work from the past and its historical horizon, (s)he does it as an individual already determined and constructed by his/her present context and background. Likewise, when a new work -regardless of the moment of its production - is regarded, the reader's - reading - background also contributes to the creation of meaning and its apprehension, since reading is not an isolated event, but part of a chain of experiences that become part of the fusion of different horizons. And as Gadamer says, "[e]l pasado propio y extraño al que se vuelve la conciencia histórica forma parte del horizonte móvil desde el que vive la vida humana y que determina a ésta como su origen y tradición. [...] comprender una tradición requiere sin duda un horizonte histórico. Pero lo que no es verdad es que este horizonte se gane desplazándose a una situación histórica. Por el contrario, uno tiene que tener siempre su horizonte para poder desplazarse a una situación cualquiera": ${ }^{3}$

So, once these considerations have been made, I intend to present a reading of two figures that belong to different historical moments - the knight and the hard-boiled private detective. And this, bearing in mind how the interplay, fusion and tension of horizons may shed light on the meaning and importance of these two sorts of figures, as they are presented in Sir Gawain and the Green Knight, and in Raymond Chandler's The Big Sleep and Dashiell Hammett's The Maltese Falcon.

John Stevens suggests that romance conventions are created to express specific experiences and, therefore, are not arbitrary. ${ }^{4}$ In this comparison between Sir Gawain, Philip Marlowe, and Sam Spade, I take into account some of the conventions of romance that point directly to the figure of the knight, conventions that, in the case of the detectives, sometimes are present as allusions that "[...] viene[n] a buscarme para obligarme a reconocer el cuerpo de intenciones que [las] ha[n] motivado, dispuesto allí como la señal de una historia individual, como una confidencia y una complicidad". 5

First of all, both Sir Gawain and the hard-boiled detectives are presented as distinct individuals. Yet, in most part of the works, their relation to society is quite different. Sir Gawain belongs to a highly ritualistic -male- aristocratic community.

\footnotetext{
${ }^{3}$ Hans-Georg GADAMER, "Fundamentos para una teoría de la experiencia hermenéutica", in En busca del texto: teoria de la recepción literaria, p. 23.

4 John STEVENS, Medieval Romance: Themes and Approaches, pp. 16-17.

${ }^{5}$ Roland BARTHES, Mitologias, p. 217.
} 
This king lay at Camelot one Christmastide

With many mighty lords, manly liegemen,

Members rightly reckoned of the Round Table,

In splendid celebration, seemly and carefree.

There tussling in tournament time and again

Jousted in jollity these gentle knights,

Then in court carnival sang catches and danced;

For fifteen days the feasting there was full in like measure

With all the meat and merry-making men could devise,

Gladly ringing glee, glorious to hear,

A noble din by day, dancing at night! ${ }^{6}$

He takes part in his community's task of "[...] proteger y purificar al mundo mediante el cumplimiento del ideal caballeresco", 7 as well as in the community's life and celebrations, both when he is in Arthur's court and when he is in foreign places, such as Bertilak's castle $(2, \mathrm{XXV})$, but this always happens within the limits imposed by his social class, since he is part of a strictly hierarchical world.

Unlike Gawain, both Marlowe and Spade are alien to their community. They are outsiders in a corrupted world since their redeeming task, and the self-confidence they need to carry it out, make them oppose their surrounding world. Moreover, the detective's world is heterogeneous and mobile, which allows him to deal with a whole range of people that belong to fairly different social strata - the detective himself is not an aristocrat - and also enables him to criticize them: "A pretty, spoiled and not very bright little girl who had gone very, very wrong, and nobody was doing anything about it. To hell with the rich".

Both the knight and the private detective are described as individuals that are fit for their task, according to their needs in their specific societies. Sir Gawain is provided with a recognized flawless reputation in terms of courtly love and chivalric vows $(3, X L I X, L X)$, a useful literal armour that can protect him from foes (2, XXV-XXVIII), and a whole series of moral characteristics and virtues which are succintly represented in the description of his highly symbolic armour.

6 "Sir Gawain and the Green Knight", in The Oxford Anthology of English Literature, vol. I, Fitt 1, III, pp. 37-47. (Further references to this poem will be immediately followed by fitt, stanza and line numbers.)

${ }^{7}$ Johan HuIZINGA, El otoño de la Edad Media, p. 91.

${ }^{8}$ Raymond CHANDLER, The Big Sleep, p. 39. 
First he was found faultless in his five wits.

Next, his five fingers never failed the knight,

And all his trust on earth was in the five wounds

Which came to Christ on the Cross, as the Creed tells.

And whenever the bold man was busy on the battlefield,

Through all other things he thought on this,

That this prowess all depended on the five pure Joys

That the holy Queen of Heaven had of her Child.

Accordingly the courteous knight had that queen's image

Etched on the inside of his armoured shield,

So that when he beheld her, his heart did not fail.

The fifth five I find the famous man practised

Were - Liberality and Lovingkindness leading the rest;

Then his Continence and Courtesy, which were never corrupted;

And Piety, the surpassing virtue. These pure five

Were more firmly fixed on that fine man

Than on any other, and every multiple,

Each interlocking with another, had no end,

Being fixed to five points which never failed,

Never assembling on one side, nor sundering either,

With no end at any angle; nor can I find

Where the design started or proceeded to its end.

Thus on his shining shield this knot was shaped

Royally in red gold upon red gules.

That is the pure Pentangle, so people who are wise are taught.

(2, XXVIII, 640-665)

Furthermore, his virtues are proved throughout the romance, as when, finally, he humbly accepts the Green Knight's challenge:

Then Gawain at Guinevere's side

Bowed and spoke his design:

"Before all, King, confide

This fight to me. May it be mine".

$$
\text { (I, XV, 339-342; also 1, XVI) }
$$

Likewise, the knight preserves his chastity and pays humble respect to his host when he courteously refuses to yield to the forceful claims of Bertilak's wife.

For that peerless princess pressed him so hotly, So invited him to the very verge, that he felt forced 
Either to allow her love or blackguardly rebuff her.

He was concerned for his courtesy, lest he be called caitiff, But more especially for his evil plight if he should plunge into sin, And dishonour the owner of the house treacherously.

'God shield me! That shall not happen, for sure,' said the knight.

So with laughing love-talk he deflected gently

The downright declarations that dropped from her lips.

(3, LXXI, 1770-1778)

Marlowe and Spade also wear a symbolical armour that suits their prowesses. They are prepared to go through both physical end emotional strains. They are tough men proficient with their guns, and cold enough so as not to be diverted from their purposes. Their strength and endurance -which are sometimes manifested through the detectives' violenceallow them to survive and to solve the crimes in which their clients are involved.

Spade's elbow dropped as Spade spun to the right. Cairo's face jerked back not far enough: Spade's right heel on the patent-leathered toes anchored the smaller man in the elbow's path. The elbow struck him beneath the cheek-bone, staggering him so that he must have fallen had he not been held by Spade's foot on his foot. ${ }^{9}$

Their physical skills are complemented and enhanced by their professional assets as detectives. They are shrewd men provided with a keen observation, quick memory, intuition, and knowledge of human nature, elements that help them to protect themselves and to find the clues of the crimes, as well as the truth about them, as when Marlowe can see a woman's "[...] pointed black slipper that showed under the plush curtain on the doorway to [his] left", ${ }^{10}$ or when Spade guesses how his partner was killed.

But he'd've gone up there with you, angel, if he was sure nobody else was up there. You were his client, so he would have no reason for not dropping the shadow on your say-so, and if you caught up with him and asked him to go up there he'd've gone. He was just dumb enough for that. He'd've looked you up and down and licked his lips and gone grinning from ear to ear - and then you could've stood as close to him

\footnotetext{
${ }^{9}$ Dashiell HaMmETt, The Maltese Falcon, p. 43.

${ }^{10}$ R. ChANDLER, op. cit, p. 49.
} 
as you like in the dark and put a hole through him with the gun you had got from Thursby that evening. ${ }^{11}$

Just as Sir Gawain, the detectives live according to a very strict, unwritten code. However, in the case of the knight the nature of the code is different since he belongs to the world of romance, where even the possible individual ideals and traits turn out to be social characteristics and imagery, as chivalry and courtly love are. ${ }^{12}$ The detective is determined to sustain a moral and ethical code of his own in a corrupt world, a code that suits his position in his world, and which turns out to be an element that increases his isolation. The detective works on a basis of absolute loyalty towards his client, towards the "forsaken" in turn, just as he is also faithful to his trade and partners. The detective suffers for the client whether (s)he deserves it or not, and covers up for him/her when it is necessary, as in The Big Sleep, where Marlowe does not tell the police that Carmen Sternwood is the murderess, so that both her old, paralized father and she - a sick girl- can be spared further disappointments and problems. In the case of Spade, although he actually disliked dumb, lascivious Archer, he considers it is his professional and moral duty to avenge his partner's death, even at the cost of Brigid $O$ 'Shaughnessy's love. ${ }^{13}$ Another aspect of the detective's code is his honesty. The detective decides when the case is finished according to his own guidelines, as when Marlowe continues his investigation even once General Sternwood has already paid him and considered his problems are solved. Likewise, he cannot be bribed nor forced to provide anyone with information or unnecesary details about the client or the case: "Who's the client?" Placidity came back to Spade's face and voice. $\mathrm{He}$ said reprovingly: "You know I can't tell you that until I've talked it over with the client". 14

Both the knight and the detective embark in adventures that allow the protagonist to show his virtues. Thus, the series of episodic adventures in which they perform prowesses, become an essential element not only in romance, ${ }^{15}$ but also in detective fiction. And these adventures are nothing but the frame, or superficial appearance, of the protagonist's quest.

"D. HAMMETT, op. cit., p. 193.

12 John STEVENS, Medieval Romance: Themes and Approaches, p. 50.

${ }^{13}$ D. HAMMETT, op. cit., pp. 197-200.

14 Ibid., p. 20.

${ }^{15}$ Northrop FRYE, Anatomy of Criticism: Four Essays, p. 186. 
These characters are engaged in two overlapping pairs of searches or purposes, and quests, a fact that easily proves its effectiveness in terms of plot, as well as in the creation of the character, and which depends very much on the searching pattern of heroism in romance where "[...] the hero is involved in a mystery; he is on a quest but does not know what he has to look for; he is engaged in a struggle but does not know who his adversary is". ${ }^{16}$ Sir Gawain leaves Camelot in order to keep his promise with the Green Knight. This first purpose is followed by the episode at Bertilak's castle, the second event in the knight's errand, and which turns out to be directly related to the first. Likewise, Spade's task is at first to discover who murdered Archer and to help Miss O'Shaughnessy. As the plot develops, he gets involved in a search for the Maltese falcon, falls in love with O'Shaughnessy, and seems to forget his initial aim. At the end, the search for the falcon finishes, while the woman is revealed as Archer's murderess, thus ending the novel with the union of different events in a single one. As regards Marlowe, he is asked to solve General Sternwood's case of blackmailing, in which Carmen Sternwood is involved. Yet, during his work Marlowe very soon finds a second element, Rusty Regan's disappearance, which at the end is found to be the accidental product of Carmen Sternwood's deeds.

Beyond these concrete events, or underlying them, there are two sorts of quests which are undertaken by Sir Gawain, Marlowe, and Spade. They are the social quest, and the individual, private quest. Gawain goes to meet the Green Knight at the Green Chapel as an emissary of Arthur's court, in order to prove the values of his community. However, there is also his quest as an individual that has to prove his own virtues. This is his opportunity to face his human nature and his true value, it is "[...] a search for the true self" 17 clearly pointed by the presence of an interlude-like episode that apparently does not have much to do with the social quest into which the knight has plunged (Fitts 2 and 3 ), but which allows him to acquire a fair appreciation of his own situation.

Spade's and Marlowe's quests somewhat adhere to the pattern created for the knight. When they try to help their clients they engage in a pursuit of truth and justice and in a fight against social corruption. They try to purge the sins of their society in a social quest in which -unlike in Gawain's - social values do not have to be proved, but transformed and purified. Nevertheless, the detective also has to confront his own private

16 J. STEVENS, op. cit., p. 80.

${ }^{17}$ Ibid., p. 78. 
situation and his relation to the world. No matter how much he strives, whatever he does is always too little and futile for his society. Besides, in spite of his claims of flawlessness, the detective himself partakes of the social corruption and is corrupted in turn: "Me, I was part of the nastiness now". 18

In the process of their quest, Gawain, Marlowe and Spade have basically two different sorts of relationships with women, mainly based on the fact that "[1]a heroicidad ha de consistir en librar o salvar a la mujer adorada del más inminente de los peligros". ${ }^{19}$ Likewise, it has to be taken into account that "[j]unto a la exaltación del flirt manteníase también la idea del amor puro, caballeresco, fiel y abnegado, que era un elemento esencial del ideal caballeresco de la vida", ${ }^{20}$ a kind of love that becomes the possibility and ground of aesthetic and moral perfection for the knight. ${ }^{21}$

The two kinds of relationships correspond to two sorts of women, the comrade-like or helpless maiden, and the witch-like, sensual woman, the first being related to the platonic, courteous conception of the beloved, whereas the second one corresponds to its dangerously erotic manifestation.

The three male characters that have been considered are or come to be bound to some women from the first group. There is Guinevere, the untouchable lady, the ideal of beloved, who is above Gawain in rank and to whom the knight owes loyalty and protection.

Then in progress to their places they passed after washing,

In authorized order, the high-ranking first;

With glorious Guinevere, gay in the midst,

On the princely platform with its precious hangings

Of splendid silk at the sides, a state over her

Of rich tapestry of Toulouse and Turkestan

Brilliantly embroidered with the best gems

Of warranted worth that wealth at any time

Could buy.

Fairest of form was this queen,

Glinting and grey of eye;

No man could say he had seen

18 R. ChandLer, op. cit., p. 139.

19 J. Hutzinga, op. cit., p. 108.

20 Ibid., p. 165.

21 Ibid., p. 152. 
A lovelier, but with a lie.

$$
(1, \mathrm{I}, 72-84)
$$

And there is also Effie Perrine, whose flirtous relationship with Spade is blurred by her being a boyish girl friend, 22 "[...] the sister of the boy who stood on the burning deck $[. . .]^{\prime 2},{ }^{23}$ an angel, ${ }^{24}$ or a man: " Y You're a damned good man, sister', he said and went out". ${ }^{25}$ But there are also some ambiguous women, since sometimes they are helpless women whose maidenhood is not so clear, or later on turns out to be a mere façade. Both Carmen Sternwood and Miss Wonderly - O'Shaughnessystart being rather forsaken women who need protection and understanding.

[...] she giggled with secret merriment. Then she turned her body slowly and lithely, without lifting her feet. Her hands dropped limp at her sides. She tilted herself towards me on her toes. She fell straight back into my arms. I had to catch her under or let her crack her head on the tessellated floor. I caught her under her arms and she went rubber-legged on me instantly. I had to hold her close to hold her up. When her head was against my chest she screwed it around and giggled at me. ${ }^{26}$

[...] "Miss Wonderly's sister ran away from New York with a fellow named Floyd Thursby. They're here. Miss Wonderly has seen Thursby and has a date with him tonight. Maybe he'll bring the sister with him. The chances are he won't. Miss Wonderly wants us to find the sister and get her away from him and back home". He looked at Miss Wonderly. "Right?"

"Yes", she said indistinctly. The embarrassment that had gradually been driven away by Spade's ingratiating smiles and nods and assurances was pinkening her face again. She looked at the bag in her lap and picked nervously at it with a gloved finger. ${ }^{27}$

These last two characters become part of the second sort of women met by the knight and the detective - the sensual witch and temptress. One of Sir Gawain's trials is his series of encounters with his host's wife, when he has to reject her courteously in order not to fail in terms

${ }^{22}$ D. HAMMETT, op. cit., pp. 5, 155, passim.

${ }^{23}$ Ibid., p. 120.

${ }^{24}$ Ibid., p. 139, passim.

${ }^{25}$ Ibid., p. 147.

${ }^{26}$ R. CHANDLER, op. cit., p. 5.

${ }^{27}$ D. HAMMETT, op. cit., pp. 8-9. 
both of chivalry and of courtly love (3). And she embodies a real temptation ("So that stately lady tempted him and tried him with questions / To win him to wickedness [...]", 3, LXI, 1549, 1550) not only because of his indebtness to the host, but also because "[...] there are also special rules for a knight 'on errand', requiring him to avoid diverting amorous entanglements". ${ }^{28}$ Moreover, behind this woman the concrete reflection of her role looms large (2, XXXIV, 947-969) - Morgan the Fay, the disagreeable woman that accompanies the host's wife and who, as an Eve figure, stands for the otherness of women that allows sensuality to be understood as evil, knowledge as witchcraft, ${ }^{29}$ aspects that are already hinted in the host's wife.

In the case of Spade and Marlowe, there are Brigid O'Shaughnessy, and both Carmen Sternwood and Vivian Regan, women who tempt the detective by means of their sexuality, which thus becomes a trap, an obstacle that has to be surmounted through the detective's "superiority". 30 They either fruitlessly try to divert the detective from his purposes, as O'Shaughnessy, or to make him depart from the his self-made rules and code, as General Sternwood's daughters do.

\begin{abstract}
The bed was down. Something in it giggled. A blond head was pressed into my pillow. Two bare arms curved up and the hands belonging to them were clasped on top of the blond head. Carmen Sternwood lay on her back, in my bed, giggling at me. [...]

"It isn't on account of the neighbors", I told her. "They don't really care a lot. There's a lot of stray broads in any apartment house and one more won't make the building rock. It's a question of professional pride. you know - professional pride. I'm working for your father. He's a sick man, very frail, very helpless. He sort of trusts me not to pull any stunts. Won't you please get dressed, Carmen?"31
\end{abstract}

Nevertheless, just as Sir Gawain, both Spade and Marlowe always manage to control the situation, even when they do get involved with women, as Spade does, because, being a knight figure, the detective has to maintain his purity and remain uncorrupted. Thus sex and women are

28 J. A. BURRow, "Sir Gawain and the Green Knight", in The New Pelican Guide to English Literature, vol. 1, p. 215.

${ }^{29} C f$. José Luis Caramés LAGE, "El ritual simbólico y mítico de Sir Gawain and the Green Knight”, in J. F. GALVÁN REULA, Estudios literarios ingleses, pp. 158-159.

${ }^{30} \mathrm{Cf}$. Jerry PALMER, La novela de misterio (thrillers): génesis y estructura de un género popular, pp. 47-72.

${ }^{31}$ R. CHANDLER, op. cit., pp. 93, 95. 
mere obstacles and temptations - and women sometimes turn out to be murderesses - that have to be overcome so that he may appear as a successful quester.

Another essential element in these characters' quest is their fall, their sin, their yielding to some sort of temptation. Gawain is able to resist the sensual allure of the lady and after every attempt on her part he has to perform a sort of cleansing ritual, such as going to mass (3, LXII, 1558), whereas detectives tend to take showers or to change into clean clothes after participating in agitated, violent events that belong to the surrounding corrupt world. ${ }^{32}$ Yet, Sir Gawain does fall in a way that afterwards turns out to be a means of survival when he accepts the lady's girdle and lies to his host (3, LXXIII-LXXVII). Moreover, this $\sin$ is followed by another when he shows some cowardice just at the moment when the Green Knight is going to hit him with the axe $(4, \mathrm{XCI})$. In the case of the detectives, they are doomed to fall for the mere fact of being lonely individuals immersed in a rotten society, and not being able to cure its illness. Because - unwillingly- being part of their society, they are also involved in corruption and somehow come to share their community's values, or at least handle its same weapons.

"Are you a loogan?"

"Sure", I laughed. "But strictly speaking a loogan is on the wrong side of the fence".

"I often wonder if there is a wrong side".

$[\ldots]$

"Oh, you think I accounted for Geiger — or for Brody — or both of them".

She didn't say anything. "I didn't have to", I said. "I might have, I suppose, and got away with it. Neither of them would have hesitated to throw lead at me".

"That makes you just a killer at heart, like all cops".

"Oh, nuts". 33

["]You don't know what I have to go through or over or under to do your job for you. I do it my way. I do my best to protect you and I may break a few rules, but I break them in your favor. The client comes first, unless he's crooked. Even then all I do is hand the job back to him and keep my mouth shut. After all you didn't tell me not to go to Captain Gregory". ${ }^{34}$

32 D. HAMMETT, op. cit., p. 123.

${ }^{33}$ R. ChANDLER, op. cit., p. 90.

${ }^{34}$ Ibid., p. 129. 
There is an essential sense of loss and defeat at the end of both Sir Gawain, and the two detectives' quest. Sir Gawain returns to his original community, which welcomes him and celebrates his being alive. However, Gawain is not the same now since he has become aware of his shameful corruption, which has led him to choose between "[...] una posible muerte y una renuncia al código caballeresco lo que establece, a lo largo del poema, una relación de duda e incertidumbre además de una mediación entre el idealismo y el engaño que llamaremos ambigüedad [...]"35 Likewise, Spade and Marlowe find that the end of their quest is also self-defeating. They have obtained no personal reward, and evil is bound to appear again. Furthermore, they may have found the truth, but they are not able to repair the damage done to society and to themselves, they are no longer flawless individuals. They are now, like Gawain, fallen angels. As John Paterson suggests, "[t]here is always at the end of the hard-boiled novel a moment of depression when the mission is completed, the enterprise ended, as if this little victory had cost too much in terms of human suffering". ${ }^{36}$

These characters find themselves trapped in relativity, since the existence of two different codes becomes evident - there are the social code, and their private codes. Therefore, they are revealed as opponents to society due to the confrontation of codes that they provoke, as well as to their mere presence as distinct, singular individuals that attempt to introduce their values in a decadent world.

The detective's isolation becomes much more evident as he has lost friends, lovers, colleagues, or at least a little self-respect and hope in the world, whereas Sir Gawain - whose task was carried out in isolation (1, $\mathrm{XXX}$ ), although he certainly belonged to his society - has to face the difference between his individual experience, and the community's response to it. Sir Gawain appears then as an individual that becomes alienated from his society since he has transcended it and its values, thus creating a more private code for himself.

The relation between these two sorts of figures - the knight and the hard-boiled detective - and their interaction produced by the reader's awareness of the fusion of horizons becomes much more evident if one takes into account how this dialectical, historical consciousness is revealed in both the poem and the novels. They display some consciousness of historicity, of the interplay of different historical moments, and of the need to profit from the acquisition of roots.

35 J. L. Caramés lage, op. cit., p. 150.

${ }^{36}$ Robin M. WINks, ed., Detective Fiction: A Collection of Critical Essays, p. 110. 
Sir Gawain and the Green Knight starts with an epic frame that summarizes the matter of Troy, which is then connected to the Arthurian cycle (1, I-II). Likewise, when Gawain's armour is described, the Pentangle and Solomon are employed in order to emphasize the ideal characteristics of the knight (2, XXVII, 620-630; XXVIII). These two elements contribute to make of Arthur and his knights the inheritors of an ancient tradition of worth praising, knightly virtues. Moreover, these allusions provide the ideal of knighthood with consistency and make it desirable and appreciated in an age already fairly posterior to Arthur's time, and when reality was different from the world depicted in romances.

In its turn, The Big Sleep relates itself to the tradition created by chivalric romances like Sir Gawain "[...] through a series of allusions. Apart from the already surveyed similarities between Gawain and Marlowe, the novel contains overt echoes of the knight figure. There are some distinct allusions to medieval past, such as Carmen Sternwood's pageboy tresses", ${ }^{37}$ and the presence of actual - chess- knights at Marlowe's apartment: "I reached down and moved a knight $[\ldots]$, 38 and the detective's ironically mentioning "The move with the knight was wrong. [...] Knights had no meaning in this game. It wasn't a game for knights", ${ }^{39}$ precisely when his knightly nature is being tested by Carmen. And one cannot dismiss the passage used as the epigraph of this essay, as well as its closing counterpart when Marlowe says that " $t]$ he portrait over the mantel had the same hot black eyes and the knight in the stainedglass window still wasn't getting anywhere untying the naked damsel from the tree", ${ }^{40}$ passages that become more meaningful if one regards the fact that, indeed, Marlowe finds a naked girl who needs his help -Carmen Sternwood.

In The Maltese Falcon, Spade is not related to knights as an individual per se, but in terms of his search. Gutman's account of the history of the Maltese falcon shows how it belongs to an ancient past, and how it has been the aim of several true questers. ${ }^{41}$ Therefore, Spade is another link in the chain of knights and knight-like individuals that have tried to find the falcon, thus becoming part of its continuous history - a history that, disturbingly enough, also includes 0 'Shaughnessy, Cairo, and Gutman, perhaps as some perversion of the knightly ideal.

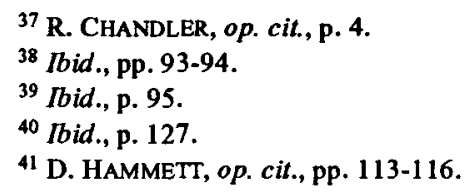


It has been shown how these different texts point to the past and to past traditions and literary works, and how they also display an awareness of this relationship. Yet, it is the reader who can -due to his/her historical consciousness, which allows him/her to take into account different levels of past and present- complete "a" and not "the" possible meaning and significance of these texts and characters, for and according to his/her own position in time.

Despite some differences between the two different figures and worlds depicted - such as the predominance of either marvellous or realistic details, which in themselves emphasize the differences between the environments depicted in the texts - both the knight and the hardboiled detective fulfill the same kind of expectations. They also play the same role within the textual and contextual limits that circumscribe them: one tries to recall myth in the realm of romance, whereas the other is constantly moving from the high to the low mimetic mode and viceversa, while trying to resemble the hero of romance, ${ }^{42}$ thus producing a movement from myth to realism. ${ }^{43}$ Gawain, Marlowe, and Spade are individuals immersed in an indifferent society, or at least in a community that is unable to understand them. If sometimes they do not seem to be absolutely fixed, unified individuals, because of their flaws, they do impose their experience as the valid one, thus rendering, among other elements, a forceful sample of the man-centredness of experience, where humanism -or its seeds and its remains- and utter phallocentrism converge. ${ }^{44}$

Both figures are the expression of past ideals placed within the limits of a society that faces a tough - or harsher- different reality. ${ }^{45}$ They belong to societies that seem to or need to cling to a past tinged by myth, a myth that gradually loses optimism and brightness, and nevertheless continues to be detached from reality.

If one takes into account the particular circumstances and characteristics of the knight and the detective, as well as the interplay of their place in time, the knight can be regarded as a myth, and the detective as a transformation and actualization of that myth, according

${ }^{42}$ Cf. N. FR YE, op. cit., pp. 33-67.

43 "Myth, then, is one extreme of literary design; naturalism is the other, and in between lies the whole area of romance, using that term to mean $[. .$.$] the tendency [. .$.$] to displace$ myth in a human direction and yet, in contrast to 'realism', to conventionalize content in an idealized direction". (I Ibid., pp. 136-137.)

${ }^{44}$ C. BELSEY, Critical Practice, p. 7, passim.

${ }^{45} C f$. J. Huizinga, op. cit. 
to Barthes observations. ${ }^{46}$ The figure of the knight becomes the embodim.nt of already established ideal systems of values - mainly, chivairy and courtly love. So the knight comes to contain ideals determined by social needs and wishes that emerge in specific historical moments. Therefore, the knight - specifically Sir Gawain - as a myth is a secondary semiological system, insofar as it employs already constructed signs as signifiers - the courteous, chivalric knight- to which a new signified is added - his individualism - thus creating the figure of this particular sort of knight.

Spade and Marlowe, being hard-boiled private detectives, are part of an artificial myth. The figure of the detective is constructed on the foundations of Sir Gawain - the knight - thus forming a tertiary semiological system that takes the knight —already a myth - as the signifier of this second myth. This signifier - the first myth-goes through several modifications in order to suit the realistic mood required by the hard-boiled detective and the hard-boiled detective novel, without losing its capacity to render allusions and analogies that point to the relation between both myths.

[...] el punto capital de todo esto es que la forma no suprime el sentido sino que lo empobrece, lo aleja, lo mantiene a su disposición. Parece que el sentido va a morir, pero se trata de una muerte en suspenso: el sentido pierde su valor pero mantiene la vida, y de esa vida va a alimentarse la forma del mito. El sentido será para la forma como una reserva instantánea de historia, como una riqueza sometida, factible de acercar o alejar en una especie de alternancia veloz: es necesario que la forma pueda volver permanentemente a echar raíces en el sentido y alimentarse naturalmente de él; sobre todo es necesario que en él pueda ocultarse. Lo que define al mito es este interesante juego de escondidas entre el sentido y la forma. ${ }^{47}$

Therefore, it is the interaction of different horizons, of the texts' past and present and of the reader's past, present, and reading background a sort of double historicity - as well as of his/her historical consciousness, which allows the existence of readings where similar patterns and characteristics in different texts are signalled. Furthermore, this dialectics of reading may become the site where mythic systems are revealed, if not created, since, as it has been shown, tracing back resemblances, and the

${ }^{46} C f$. R. BARTHES, op. cit., pp. 199-257.

${ }^{47}$ Ibid., pp. 209-210. 
construction of meaning and patterns, depend to a great extent on a conscious, active participation of the reader - who stands on a vantage point-a participation that can be justly regarded as an essential element in the dialogue between reader and text. A dialogue where the past can be the foundation of the present, but also where the present modifies our appreciation of the past in such a way, that every new reading, insofar as it may suppose an understanding of the text, also implies the possibility of a valid new, enriching interpretation.

\section{Bibliography}

Barthes, Roland, Mitologias. Trans. Héctor Schmucler. México, Siglo XXI, 1989.

Belsey, Catherine, Critical Practice. London, Methuen, 1988.

Bolleau, Pierre and Thomas NarCeJAC, La novela policial. Trans. Basilia Papastamatín. Buenos Aires, Paidós, 1968. (Letras mayúsculas, 7)

Burrow, J. A., "Sir Gawain and the Green Knight", in The New Pelican Guide to English Literature, vol. 1, part I. Ed. Boris Ford. Harmondsworth, Penguin Books, 1982, pp. 208-223.

Chandler, Raymond, The Big Sleep. New York, Vintage Books, 1988. (Vintage Crime)

Chandler, Raymond, "The Simple Art of Murder", in Pearls are a Nuisance. Harmondsworth, Penguin Books, 1964, pp. 181-199. (Penguin Crime)

FRYE, Northrop, Anatomy ofCriticism: Four Essays. Princeton, Princeton University Press, 1973.

GADAMER, Hans-Georg, "Fundamentos para una teoría de la experiencia hermenéutica", in En busca del texto: teoria de la recepción literaria. Ed. Dietrich Rall. México, UNAM, 1987, pp. 19-29. (Pensamiento social) 
Galván Reula, J. F., ed., Estudios literarios ingleses. Edad Media. Madrid, Cátedra, 1985. (Crítica y estudios literarios)

Hammett, Dashiell, The Maltese Falcon. London, Pan Books, 1975.

Huizinga, Johan, El otoño de la Edad Media. Trans. José Gaos. Madrid, Alianza Editorial, 1990. (Alianza universidad, 220)

IsER, Wolfgang, The Act of Reading: A Theory of Aesthetic Response. Baltimore, The Johns Hopkins University Press, 1978.

JAUSS, Hans Robert, "Literary History as a Challenge to Literary Theory", in New Literary History: A Journal of Theory and Interpretation, vol. II, no. 1, 1970-1971, pp. 7-37.

KeEN, Maurice, Chivalry. New Haven, Yale University Press, 1984.

PALMER, Jerry, La novela de misterio (thrillers): génesis y estructura de un género popular. Trans. Mariluz Caso. México, FCE, 1983. (Colección popular, 231)

"Sir Gawain and the Green Knight", in The Oxford Anthology of English Literature, vol. I. General eds. Frank Kermode and John Hollander. New York, Oxford University Press, 1973, pp. 286-348.

STEVENS, John, Medieval Romance: Themes and Approaches. New York, W. W. Norton \& Company, 1974.

WINks, Robin W., ed., Detective Fiction: A Collection of Critical Essays. Englewood Cliffs, Prentice-Hall, Inc., 1980. 